Profitability drivers of Islamic banks rania salem hossameldin 2019/4/8 تاريخ قبول النشر

\title{
Profitability drivers of Islamic banks: A global panel investigation
}

\author{
Rania Salem Hossameldin Ahmed
}

\begin{abstract}
This paper analyzes the profitability of 108 Islamic banks operating across 35 countries over the period 2005-2015 using the GMM estimator technique. We investigate the global panel of Islamic banks under various economic conditions. We study how bank specific factors and macroeconomic conditions impact bank profitability, measured by the return on average assets (ROAA), the return on average equity (ROAE), and the net interest margin (NIM), under different banking environments. The paper investigates the factors that affect the profitability of Islamic banks. The results reveal that bank size, credit risk, CIR, and deposit growth rates have a negative impact on profitability, while bank age, capital adequacy, and liquidity risk positively affect profitability. Moreover, our analysis show that macroeconomic factors measured by GDP growth rates and inflation have a positive impact on profitability. These findings suggest that, based on the current financial reporting system, Islamic banks resembles conventional banks in terms of profitability determinants. JEL classification: G20; G21; Z12
\end{abstract}

Keywords: Islamic banks; Profitability determinants; Global panel; GMM system; Bank performance; Financial analysis; Conventional banks; risk analysis; Credit risk; AAOIFI standards 
Profitability drivers of Islamic banks rania salem hossameldin 2019/4/8 تاريخ قبول النشر

\section{INTRODUCTION}

The existing literature provides comprehensive studies on the financial performance of banks. Conventional bank performance has been studied in specific regions, across several countries, or in individual countries (Goddard, Molyneux, and Wilson, 2004; Staikouras and Wood, 2004; Pasiouras and Kosmidou, 2007; Athanasoglou et al.; 2008; Kosmidou, 2008; Sufian, 2009; Dietrich and Wanzenried, 2011; Javaid, Anwar, Zaman, and Gafoor, 2011; Dietrich and Wanzenried, 2014; and Petria, Capraru, and Ihnatov, 2015). In recent decades, Islamic banking appeared as a quickly growing player in the financial industry. Islamic banks witnessed accelerated growth rates, ranging between $15 \%$ and $20 \%$, and in most cases, operated under dual financial systems. The Islamic Financial Services Board (IFSB), Islamic Development Bank (IDB), and Islamic Research and Training Institute (IRTI) reported that Islamic banking assets reached USD 660 billion by the end of 2007 (IFSB, 2010) and USD 1.6 trillion by 2015 (Abedifar et al., 2015). The growth of Islamic banks worldwide urged along the need for global regulators that aimed at standardizing Islamic banking operations. The most active regulating body being the Accounting and Auditing Organization for Islamic Financial Institutions (AAOIFI).

The dual nature of the financial and regulatory environments under which Islamic banks operate attracted researchers to investigate the performance of Islamic banks versus their conventional counterparts (see for e.g. Abedifar et al., 2016; Beck et al., 2013; Ben Khediri et al., 2015; and Olson and Zoubi, 2016). Some studies revealed few differences among Islamic and conventional banks in terms of performance, such as

Olson and Zoubi (2008) and Mokni and Rachdi (2014). Other researchers, like Beck et al. (2013), Trad, Trabelsi, and Goux (2017), and Zarrouk et al. (2016), concluded that there are no major differences between both bank groups, specifically in terms 
of performance determinants, where the factors affecting conventional and Islamic banks profitability are analogous. While the comparative study of Islamic and conventional banks is essential to identify the differences and/or similarities of both banking models, the study of the Islamic banking industry on its own has been relatively marginalized in the literature. Furthermore, with the growth of Islamic banks and the significant role of regulating Islamic finance institutions such as the AAOIFI in standardizing Islamic banking operations, it has become necessary to study Islamic banking operations equally across all countries. Understanding the operations of Islamic banks in different countries promotes a more systematic approach towards setting efficient policies and regulations. Such policies aim at higher sustainable profits and more efficient risk management systems in Islamic banks. Towards that direction, investigating determinants of profitability in Islamic Banks is a key pillar for the development of the industry.

In this paper, we studied the determinants of Islamic banks' profitability worldwide covering 108 banks operating in 35 countries. We used unbalanced panel data to examine the determinants of profitability, classified into bank-specific factors and macroeconomic factors, over the period 2005-2015. This research identifies the common profitability determinants of Islamic banks globally. Hence, adding to the existing literature by providing a complete analysis of Islamic banks operating all over the world across different countries.

The remainder of this paper is organized into five sections. Section two reviews the existing literature regarding the performance of Islamic banks. Section three presents the determinants of profitability and elaborates on the selected variables and their expected effects on bank performance within our sample. Furthermore, we extend our data description before we proceed to section four in which the methodological approach adopted is presented. Section five presents the empirical results. Finally, section six concludes the paper. 
Profitability drivers of Islamic banks rania salem hossameldin 2019/4/8 تاريخ قبول النشر

\section{PERFORMANCE OF ISLAMIC BANKS}

The existing literature on bank performance offers a comprehensive analysis of bank-specific, industry-specific, and macroeconomic determinants for conventional banks. A large number of empirical studies examining the determinants of bank profitability have been conducted either across several countries or in individual countries. Recent studies include, but are not limited to, Goddard et al. (2004), Staikouras and Wood (2004), Pasiouras and Kosmidou (2007), Izhar and Asutay (2007), Athanasoglou et al. (2008), Kosmidou (2008), Sufian (2011), Dietrich and Wanzenried (2011), Javaid, et al. (2011), and Dietrich and Wanzenried (2014), where most of the research studied developed economies with only few papers examining emerging economies.

The Islamic banking literature on performance and efficiency is less comprehensive as it is considered a relatively new area of research in mainstream banking. Despite its novelty, various studies compared the performance of Islamic banks, whether with regards to efficiency or profitability, to their conventional counterparts. More recently, research has also been directed to competition, profit and loss sharing behaviors, risk, financial inclusion, and small business financing. Such studies are known for their comparative nature, where researchers analyze and compare Islamic banks to conventional banks.

The empirical studies investigating the determinants of Islamic banks' profitability have focused their analysis either on individual countries or on cross-country analysis. Studies by Ahmed and Khababa (1999), Bashir (1999), Samad and Hassan (1999), Majid et al. (2003), El-Gamal and Inanoglu (2002), Daly and Frikha (2015), and Ramlan and Adnan (2016) focused their analyses on individual countries. Other studies by Hassan and Bashir (2003), Majid et al. (2003), Mohamad et al. (2008), Bader et al. (2008), Mokni and Rachdi (2014), and Daly and Frikha (2015) examined a panel data set across several countries. More 
focus has also been directed towards the Middle Eastern and North African (MENA) and the Gulf Cooperation Council (GCC) regions where the largest Islamic banks are located. Examples of studies examining individual countries are Ahmed and Khababa (1999) in Saudi Arabia, Ramadan, Kilani, and Kaddumi (2011) in Jordan, Al-Tamimi (2010) in the United Arab of Emirates (UAE), and Daly and Frikha (2015) in Bahrain. The empirical results of the above-mentioned studies vary based on the data sets, time periods, economic and banking environments and countries.

Beck et al. (2013) provided the most comprehensive study on the performance of Islamic and conventional banks by investigating a sample of 88 Islamic banks and 422 conventional banks across 141 countries using different regression methods (OLS, fixed effects, and Robust regression). Their results showed few significant differences between both bank groups. Others, like Mokni and Rachdi (2014) use the generalized method of moments (GMM) to evaluate and compare the determinants of profitability for Islamic and conventional banks in the MENA region. They find that bank profitability is affected by a high degree of government intervention. Moreover, they conclude that the factors affecting bank profitability differ from Islamic banks to conventional banks. On the contrary, Zarrouk et al. (2016) provided evidence that profitability determinants of conventional and Islamic banks are alike. Yet, their investigation shows that Islamic banks can earn higher profits through non-financing activities. Olson and Zoubi (2011) explore the profitability determinants of Islamic and conventional banks in ten MENA countries and revealed that banks profitability is positively affected by increase in bank size, loans to revenue, market concentration, GDP growth, and equity capital to assets. On the other hand, variables such as liquidity levels, provisions for loan losses, cost inefficiencies, credit risk, and debt ratios have been associated with lower bank profits.

Daly and Frikha (2015) use Data Envelopment Analysis (DEA) to test the determinants of bank performance in Bahrain on a 
comparative sample of conventional and Islamic banks. In their study, they pointed out that the most important factors of performance in Islamic banks were the size of the bank and the growth in customers' deposits. Additionally, they indicated that government intervention had a negative impact on conventional bank performance. Similarly, Rosman, Wahab, and Zainol (2014), use DEA to explore the efficiency level of Islamic banks and examine the impact of bank-specific and risk factors on efficiency during the financial crisis in Middle Eastern and Asian countries.

On one hand, some studies such as Samad (2004) and Rosly and AbuBakar (2003) concluded that Islamic banks and conventional banks perform differently, while other studies indicated that Islamic and conventional banks reported similar performance, such as Majid et al. (2003), Mohamad et al. (2008), and Beck et al. (2013). For example, Abedifar, et al. (2013) used a sample of 553 banks across 24 countries over the period 1999 and 2009, to investigate the risk and stability levels in Islamic and conventional banks. They report that Islamic banks appear to be more capitalized and more profitable when compared to conventional banks. On the other hand, Zarrouk et al. (2016) reported that there are no differences in the profitability determinants between Islamic and conventional banks. Bashir (1999) and Grassa (2012) focused only on Islamic banks. Bashir (1999) examined only 2 banks in Sudan from 1979 to 1993. Bashir (1999) used OLS regression method to analyze the relationship between risk and profitability. Grassa (2012) used a larger sample of 42 Islamic banks in the GCC countries and used multiple regression analysis to conclude that Islamic banks investing in Profit and loss sharing (PLS) financing hold higher risk.

To conclude, the existing literature provides a comprehensive examination of the effects of Islamic banks' profitability determinants. However, very few studies combined the analysis to cover the international body of Islamic banks across all 
countries. As the Islamic banking system is coherently growing across the world with global institutions, such as the Accounting and Auditing Organization for Islamic Financial Institutions (AAOIFI) that aims at standardizing Islamic banking operations, it has become essential to investigate equally bank-specific and macroeconomic determinants that affect Islamic banks across all countries worldwide. Hence, this research aims at identifying the effect of bank-specific and macroeconomic determinants on Islamic banks worldwide. Our study fills an important gap in the literature by covering all Islamic banks in different countries and under various economic environments.

Empirical research may result in various outcomes based on the inputs of data sets, time periods, and region or country. Yet, the literature provides consensus in terms of the factors that affect the profitability of banks. The Return on Average Assets (ROAA), Return on Average Equity (ROAE), and Net Interest Margin are common proxies used to measure profitability that is affected by a number of internal and external determinants (Dietrich and Wanzenried, 2014). Previous research have categorized determinants of bank profitability into bank-specific variables such as capital ratio, operational efficiency, and bank size, macroeconomic variables such as GDP and inflation, and industry-specific variables such as industry concentration. Industry specific determinants require industry information per country and since the available industry-specific data include information on both Islamic and conventional banks, it is not possible to collect the relevant data for Islamic banks without the inclusion of conventional banks. Hence, we exclude the examination of industry-specific variables as a bank determinant of Islamic banks profitability, as our main emphasis is on Islamic banks. We focused on examining the determinants of Islamic banks performance through studying bank-specific and macroeconomic variables. The following section outlines our variable selection based on determinants of bank profitability. 
Profitability drivers of Islamic banks rania salem hossameldin 2019/4/8 تاريخ قبول النشر

\section{Determinants of bank profitability and Variable selection \\ Dependent variables}

We use ROAA, ROAE, and NIM as our dependent variables in examining the performance of banks. The three measures are commonly used in the literature as proxies for profitability (Dietrich and Wanzenried, 2014; Tan, 2016). The ROAA reflects the relative return generated by the bank's assets and is considered the most common profitability measure (Golin, 2001). It shows the effectiveness of the bank management to generate profits from its assets. The ROAA is computed as the ratio of net profits after tax to the average total assets. The ROAE is the second profitability measure used in our analysis and shows the net return of the capital invested by shareholders, which reflects on the financing and leverage decisions of banks. The ROAE is the after tax net profits to the average total equity. We calculate the returns based on average yearly balance sheet figures, assets and equity, because they are more accurate than the end of year values (Goddard et al., 2004). Finally, the NIM focuses on profit earned on interest (lending) activities. The NIM is the net interest income to the total assets (Dietrich and Wanzenried, 2014).

\subsection{INDEPENDENT VARIABLES}

The determinants of banks' profitability are split into three large groups throughout the existing literature: bank-specific determinants, macroeconomic (external) determinants, and industry-specific determinants (Tan, 2016). In our research, we include the first two sets of determinants. Industry concentration, which is generally measured by the Herfindahl-Hirschman index $(\mathrm{HH})$, is the most common variable measured under industryspecific determinants. This measure focuses on either the five largest banks within the industry (Athanasoglou et al.; 2008; Dietrich and Wanzenried, 2014) or banking sector assets as a whole (Tan, 2016; Pasiouras and Kosmidou, 2007). In this sense, calculating the $\mathrm{HH}$ index in the traditional manner would not 
accurately reflect the degree of Islamic banks development within the industry. Hence, we exclude industry-specific determinants from our analysis. For the first set of determinants, which represents bank-specific variables, we include capitalization, credit risk, bank size, cost income ratio, growth of deposits, bank age, bank ownership nature, bank ownership concentration, asset quality, and liquidity.

One of the most commonly used measures of risk in the literature is capitalization or capital adequacy. Capitalization reflects the percentage of assets that are covered by the bank's equity (Athanasoglou et al., 2008; Tan, 2016). Based on Dietrich and Wanzenried (2014), capitalization has both positive and negative effects on performance. While banks with higher levels of capital are considered to hold lower risk, and hence lower returns (Berger, 1995), still, the lower risk leads to lower funding costs through an increased level of credit worthiness or reduced need for external funds (Tan, 2016). Hence, we hypothesize that capitalization may have a positive or negative impact on profitability. The direction of this variable is left to be proven empirically without prior expectations. We measured capital adequacy ratio by dividing the equity by the total assets

because other risk-weighted capital ratios are not available by most banks in our sample as they are highly dependent on bank internal models.

Another important measure of bank risk that affects a bank's performance is credit risk. Credit risk reflects the ability of debtors to fulfill their obligations to the bank. There are several measures of credit risk in the literature. For the purposes of this research, loan loss provisions to total loans was used. The higher the ratio, the higher the credit risk of the bank, thus affecting the bank's profitability negatively. Hence, we base our expectations on that rationale in conjunction with the literature (Dietrich and Wanzenried, 2014; Tan, 2016). Moreover, liquidity risk is an important risk measure in banks that affects profitability. The effect of liquidity risk on profitability levels is inconsistent in the 
literature. Molyneux and Thornton (1992) reveal a negative impact of liquidity on profitability, unlike Tan (2016) who concluded there was a positive effect. We measure liquidity risk by dividing the total loans by the total assets following Goddard et al. (2004) and Tan (2016). Larger figures of this ratio indicate lower liquidity levels, yet imply higher interest income generated as a result of the increase of loans. On one hand, adequate liquidity levels enable banks to meet their obligations even under difficult situations, and on the other, having higher liquid assets lowers returns and profitability. Our expectation is lower liquidity risk increases the stability of banks, yet under the expense of lower profitability levels. Therefore, we hypothesize a negative impact of credit risk on profitability of Islamic banks and a positive impact of liquidity risk on profitability.

Bank size and age are other bank-specific determinants which significantly affect banks profitability. Based on the literature, the effect of bank size on profitability can either be positive (Pasiouras and Kosmidou, 2007; Trad et al., 2017) or negative (Stiroh and Rumble, 2006). The negative effect on performance may be related to bureaucracy of some large banks, among other reasons. As we expect a level of bureaucracy in some Islamic banks resulting from the banking environment under which they operate, we hypothesize that bank size may have a positive or negative impact on profitability. Similar to Tan (2016), we measure bank size by calculating the natural logarithm of total assets. As regards to bank age, studies suggest that the longer established the bank, the higher is its expected profitability compared to new entrants (Beck et al. 2013). However, in a study (Dietrich and Wanzenried, 2014), the opposite view was empirically proven as newer banks turned out to have higher profitability because they were able to successfully pursue new profit opportunities compared to longer traditional banks. As Islamic banks face barriers of entry on both the regulatory and competition levels, we do not expect new Islamic banks to have 
higher profits. Thus, we conclude our hypothesis at a positive impact of bank age on profitability.

Additionally, we account for deposit growth as a determinant for banks profitability as it is assumed that the more branches a bank has, the more deposits it is able to attract, which means lower cost of funds (Sufian, 2011), and hence higher profitability. We hypothesize a positive impact of deposits on profitability. We calculate the deposit growth by the natural logarithm of customer deposits. Furthermore, we measure the bank's operational efficiency by the Cost Income Ratio (CIR); which is equivalent to the total expenses over total revenues. It measures the effect of efficiency on bank profitability and is expected to have a negative impact on performance (Dietrich and Wanzenried, 2014). Our hypothesis follows the literature findings that CIR has a negative impact on profitability.

With regard to ownership, there appears to be no consensus in the literature regarding the impact of bank ownership on profitability. Some studies such as Iannotta et al. (2007) find that whether a bank is privately-owned or state-owned does not affect its performance. Nevertheless, Micco et al. (2007) reveal that stateowned banks operating in developing countries tend to have a lower profitability, lower margins, and higher overhead costs compared to privately-owned banks. In industrialized countries, however, this relationship has been found to be much weaker. While in another study on Swiss banks, state-owned banks tend to have higher profitability after the financial crisis of 2007 , as investors found them to be a safer investment than privatelyowned banks (Dietrich and Wanzenried, 2014). Since our sample includes both developed countries, such as the UK, emerging countries, such as Malaysia, and several developing countries, we keep the expected direction under investigation. Hence, our hypothesis is that ownership structure may result in a positive or negative impact on profitability. Furthermore, we investigate whether being listed at a stock exchange has an impact on bank profitability. As a potentially positive impact, the bank's 
shareholders, the analysts, and the financial markets put listed banks under pressure to become more profitable. As a potentially negative impact, listed banks, unlike unlisted banks, face additional costs created by many reporting and other requirements. Therefore, our hypothesis regarding the overall effect remains indeterminate and to be tested.

The ownership structure is divided into the nature of the ownership structure whether the ultimate owner, who represents more than $50 \%$ of a private entity or government-owned. And a third option exists which is a mix of both ownership natures. Thus, ownership nature is measured by 2 dummy variables: PUB; a dummy variable that equals 1 if the bank's ultimate owner is either a national or local government, and zero otherwise. PRIV; a dummy variable that equals 1 if the ownership is for a private entity (banks, mutual banks, investment banks) and zero otherwise. An additional dummy variable is added to measure whether a bank is listed in the stock market: LIST; a dummy variable that equals 1 if the bank is listed in a stock market, and zero otherwise. We use this as a proxy for ownership dispersion and we do not have a clear

expectation for its coefficient sign. Incentive problems arising from the separation of ownership and control become more severe when ownership is more dispersed. Consequently, we might expect negative coefficient signs with the dependent variables. On the other hand, a bank whose shares are publicly traded is supposed to be positively affected by market discipline mechanisms. If this is the case, a positive coefficient will result with the dependent variables (Iannotta et al., 2007).

In our research, since the sample included Islamic Banks operating globally, we included macroeconomic determinants to account for macroeconomic variations. Thus, we included real growth domestic product (GDP) (Dietrich and Wanzenried, 2014; Athanasoglou et al.; 2008), growth and inflation expectations (Tan, 2016; Athanasoglou et al., 2008; Pasiouras and Kosmidou, 2007) following the literature. Most studies have shown a positive 
relationship between inflation, central bank interest rates, GDP growth, and bank profitability (e.g. Molyneux and Thornton, 1992; Demirguc-Kunt and Huizinga, 1999; Athanasoglou et al., 2008).

Inflation is an important determinant of bank performance. The impact of inflation on bank profitability was firstly examined by Revell (1979) and further investigated by Perry (1992). Both argued that the effect depends on whether inflation is anticipated or unanticipated: if inflation rate is fully anticipated, banks can adjust the interest rates or manage the operating expenses accordingly to make the revenues increase faster than the costs, which leads to higher profitability, while if inflation is not fully anticipated, the loan losses will be accumulated, which leads to a decrease in bank profitability, thus there is no prior expectation for the impact of inflation on bank profitability (Tan, 2016). We also use GDP growth rate as an important macroeconomic variable. Some researchers argue that it has a positive impact on bank profitability due to the fact that demand for lending increases during cyclical upswings. On the other hand, other studies (Tan and Floros, 2012) conducted in other countries, such as China, show that GDP growth rate has a negative impact on bank profitability. They suggest that higher economic growth improves the business environment and lowers the bank entry barriers. The consequently-increased competition dampens bank profitability. To conclude our hypothesis regarding the macroeconomic variables, we expect that inflation and GDP growth rates may have a positive or negative impact on Islamic banks' profitability. Table 1 provides a summary of our variable selection and the expected effect of each on bank performance. 
Table 1: Summary of Variables

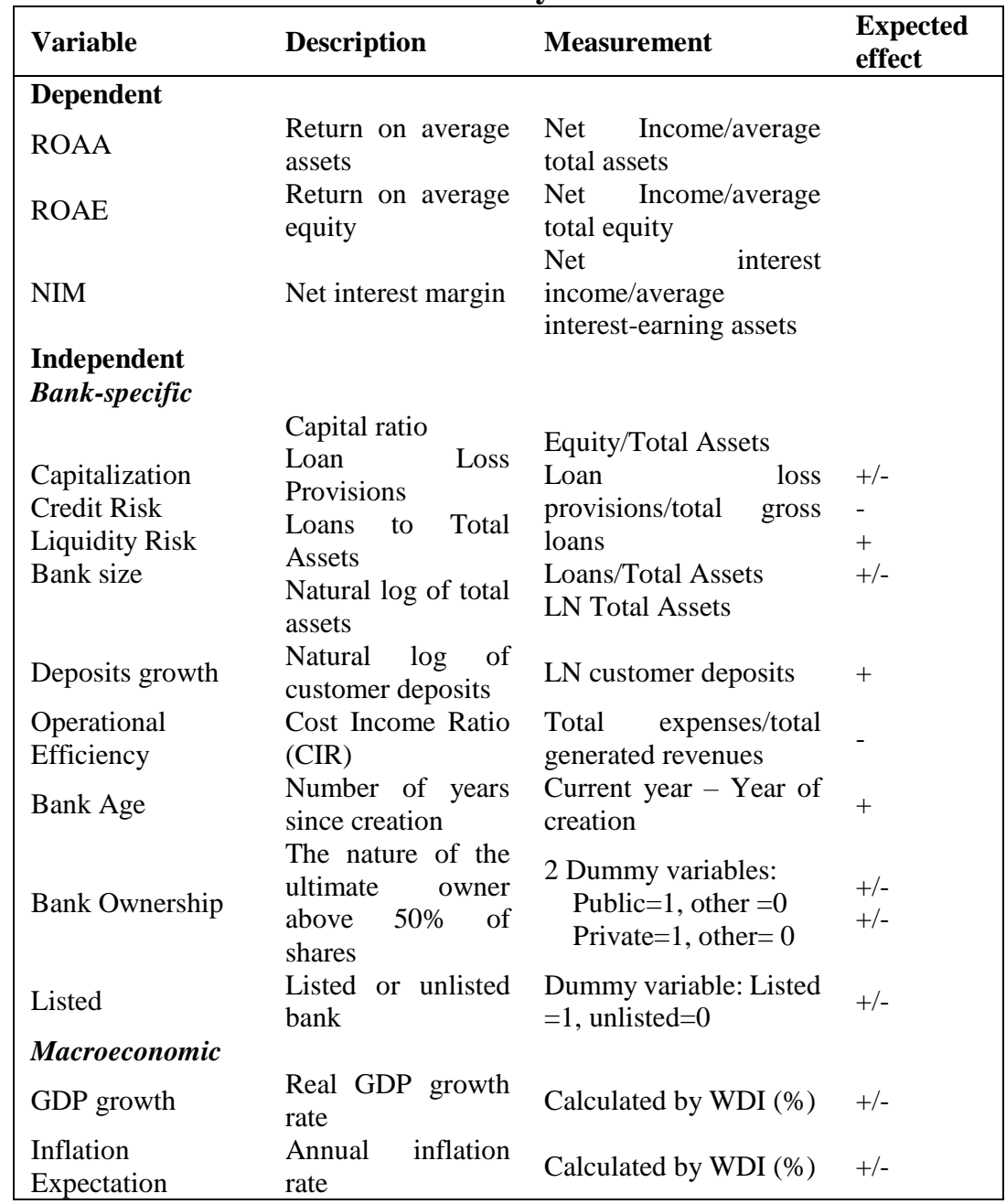




\section{DATA AND METHODOLOGY 3.1 DATA AND DESCRIPTIVE STATISTICS}

This study used unbalanced panel data of 108 Islamic banks operating actively and registered at their respective Central Banks worldwide across 35 countries over the years from 2005 to 2015. Panel data allows the study of the behavior of individual banks over time and across space (Baltagi, 2005; Gujarati, 2003). We use cross-country bank-level data downloaded from the BankScope database compiled by Fitch/IBCA/Bureau Van Dijk. BankScope to facilitate the comparison among different banks as the database converts the data into common international standards. The initial search resulted in a sample of 167 Islamic banks across the globe. For further reassurance, the list of banks were cross-checked with the Central Banks of the respective countries to confirm our sample selection for each individual country, which resulted in the exclusion of 10 investment banks from our sample. Furthermore, the regression results rendered a final sample of 108 banks, after excluding banks with missing variables. Macroeconomic variables, per capita real GDP and annual inflation rates, were collected from the World Development Indicators (WDI).

A descriptive analysis of the data is shown in Table 2. Iran, which has a fully-fledged Islamic banking system, represents the largest Islamic banking market, followed by the GCC countries, and Malaysia (Table A-8 presents more details regarding the number of observations, mean, highest, and lowest figures for each dependent and independent variable per country). On average, Islamic banks show a ROAA of $0.91 \%$ and a ROAE of $8.73 \%$ over the period 2005 to 2015 . The variation between the mean and median reflects the presence of differences in the level of profitability among banks in our sample. The capital adequacy ratio is $20.26 \%$ on average, yet varies significantly among banks. Many Islamic banks are newly established and thus have a smaller number of observations (years). We handle this discrepancy by 
considering the bank age as one of our determinants in the model. We find that the oldest Islamic banks operate in Iran, Malaysia, and the GCC, with the oldest being established 100 years ago and the youngest 2 years ago. We observed high standard deviations for most of the variables, which could refer to the existence of outliers. Due to the existence of outliers, the median and Interquartile range (IQR) are recommended to represent the central and dispersion measures of the sample. As long as the mean is less than the median, the dataset is negatively skewed which means the frequency of high values is bigger than the low ones.

Table 2: Summary of Descriptive statistics

\begin{tabular}{llllll}
\multicolumn{1}{c}{ ROAA } & Obs. & Mean & S.D. & Median & $\begin{array}{l}\text { Interquartile } \\
\text { Range }\end{array}$ \\
\cline { 2 - 6 } ROAE & 1069 & 0.91 & 7.47 & 1.12 & 1.90 \\
NIM & 1069 & 8.73 & 18.10 & 9.15 & 13.98 \\
Age & 1046 & 5.15 & 18.70 & 3.34 & 2.80 \\
Bank Size & 1617 & 23.30 & 17.80 & 19.00 & 23.00 \\
GDP Growth & 1070 & 14.12 & 1.98 & 14.26 & 3.01 \\
Inflation & 1642 & 4.63 & 3.86 & 4.83 & 3.25 \\
Capital adequacy & 1551 & 8.51 & 8.62 & 6.20 & 8.36 \\
Credit Risk & 1070 & 20.26 & 34.63 & 13.89 & 16.77 \\
Cost to Income Ratio & 1030 & 4.07 & 42.42 & 0.47 & 1.29 \\
Annual Growth of Deposits & 1026 & 74.24 & 85.50 & 55.95 & 37.99 \\
Liquidity Risk & 851 & 20.32 & 64.98 & 15.52 & 30.44 \\
\hline Table A-8 in the appen & 1028 & 48.64 & 23.97 & 55.10 & 35.05 \\
\hline
\end{tabular}

Table A-8 in the appendix provides a breakdown of the descriptive statistics for each country of the 35 under analysis. The correlation matrices presented in Tables A-2, A-3, and A-4 in the appendix conclude the absence of multicollinearity between the variables, which is an essential outcome for the estimation of the regression models. We studied the determinants of Islamic banks profitability across countries with different income levels and different uncertainty, which is reflected in the dispersion levels. 


\subsection{METHODOLOGY}

We followed Athanasoglu et al. (2008) and Dietrich and Wanzenried (2011) and used a linear model, as follows, to investigate the determinants of bank profitability:

PROFIT ABILITY $Y_{i, t}$

$$
\begin{aligned}
& =\alpha+\text { PROFITABILITY }_{i, t-1}+\sum_{j=1}^{J} \beta_{j} X_{i t}^{J}+\sum_{l=1}^{L} \beta_{j} M_{i t}^{J} \\
& +\varepsilon_{i t}
\end{aligned}
$$

PROFITABILITY ${ }_{\mathrm{i}, \mathrm{t}}$ is the profitability of bank $i$ (where $i=1, \ldots$, $N$ ) at time $t$ (where $t=1, \ldots, T$ ), $\alpha$ is a constant term, $\mathrm{X}_{i t}$ are the bank-specific variables, $\mathrm{M}_{i t}$ are the macroeconomic variables, and $\varepsilon_{i t}$ is the one-way component error term with $v_{i}$ is the unobserved bank-specific effect and $\varepsilon_{i t}$ is the idiosyncratic error, representing a one-way component regression model $v_{i} \sim \operatorname{IIDN}\left(0, \sigma_{v}^{2}\right)$ and $u_{i t} \sim \operatorname{IIDN}\left(0, \sigma_{u}^{2}\right)$. Due to the specific characteristics of banks reflected in informational opacity, sensitivity to macroeconomic shocks, and entry barriers, bank profits tend to persist over time (Berger et al., 2000). Accordingly, we include a lagged dependent variable PROFITABILITY $Y_{i, t-1}$ among the regressors and $\delta$ is the speed of adjustment to equilibrium. A value between 0 and 1 for $\delta$ shows persistence of profits, a value closer to 1 reflects an industry that is less competitive.

Due to the dynamic nature of our model, we use techniques for dynamic panel estimation. As explained by Baltagi (2001), the least squares estimation methods ${ }^{1}$ will produce biased and inconsistent estimates. Accordingly, we used the Generalized Method of Moments (GMM) to estimate the model parameters as

Least Square Dummy Variable estimation method is a traditional way to run panel data models. The implicit inclusion of several dummy variables may result in omitting some independent variables due to the presence of perfect multicollinearity and can prevent a particular model to be estimated. Hence, the resulting estimation would far from accurate. Despite that, LSDV estimation is conducted in both dynamic and static cases where the lagged values of the dependent variables in the models of study are included and when it is not included respectively (see Appendix A-5 and 6 ). 
proposed by Arellano and Bond (1991) and developed by Arellano and Bover (1995). This method depends mainly on using the lagged values of the dependent variables of study in level and differences as instruments. Moreover, this technique solves the endogeneity problem that may arise in estimating bank profitability determinants.

The robustness of the results is confirmed by applying three different measures of profitability (ROAA, ROAE, and NIM). We estimate the three following linear models to test for the determinants of profitability for Islamic banks:

$$
\begin{aligned}
& \text { Panel A } \quad R O A A_{i, t}=\alpha+R O A A_{i, t-1}+\sum_{j=1}^{J} \beta_{j} X_{i t}^{J}+\sum_{l=1}^{L} \beta_{j} M_{i t}^{J}+\varepsilon_{i t} \\
& \text { Panel B } \\
& R O A E_{i, t}=\alpha+R O A E_{i, t-1}+\sum_{j=1}^{J} \beta_{j} X_{i t}^{J}+\sum_{l=1}^{L} \beta_{j} M_{i t}^{J}+\varepsilon_{i t} \\
& \text { Panel C } \\
& N I M_{i, t}=\alpha+N I M_{i, t-1}+\sum_{j=1}^{J} \beta_{j} X_{i t}^{J}+\sum_{l=1}^{L} \beta_{j} M_{i t}^{J}+\varepsilon_{i t}
\end{aligned}
$$

Several tests are conducted after estimating the three models to test for reliability. The Sargan-Hansen test null hypothesis is over-identifying restrictions are valid in GMM estimation. That is to ensure that the usage of certain chosen instruments' structure is suitable for the mentioned models. The Arellano Bond test is performed to detect the existence of autocorrelations of order one and two in the residuals obtained from the estimated models, based on its null hypothesis of the absence of the autocorrelation in residuals. To examine whether the variables of the study are stationary or not and to investigate the presence of unit root, Levin-Lin and Chu (LLC), Im, Persran and Shin (IPS), and ADF tests have been applied (see Appendix A-7) on the panel based on the common/individual processes, where the null assumes the panels contain unit root with intercept and trend specification. The tests are performed to avoid obtaining spurious regression results 
Profitability drivers of Islamic banks rania salem hossameldin 2019/4/8 تاريخ قبول النشر

\section{EMPIRICAL RESULTS}

Table 3 summarizes the empirical results for our three models. The null hypothesis $\mathrm{H}_{0}$ is not rejected implying the validity of the instrumental variables used in constructing the models. Our estimation results show stable coefficients. The p-value of Waldtest is less than $1 \%$ indicating a strong fit and the reliability of the models. The equations indicate a relatively weak autocorrelation effect in the residuals of order one and two (the probabilities of Arellano-Bond tests AR (1) \& AR (2) are greater than 1\%). However, since AR (2) P-value is greater than the significance level of 5\%, it can be inferred that the over-identifying restrictions of the estimates are valid. Moreover, the

Sargan-Hansen test proves that the over-identification for restrictions for GMM estimation is strongly valid given that the $\mathrm{P}$-value is 1.000. The number of observations used in running GMM estimation for ROAA, ROAE, and NIM models are 1576, 1576, and 1570, respectively. The number of banks that rendered results under the three models are 108 Islamic banks, over the period of time between 2005 and 2015.

The estimated coefficients of the first lagged dependent variables in the relative three models are highly significant with the respective coefficients for ROAA, ROAE, and NIM as follows: $0.2678,0.2185$, and 0.6409 at all significance levels. This confirms the dynamic character of the models specification. Additionally, the value of the coefficients of the lagged variables are closer to 0 than 1 , which reflects the highly competitive nature of the industry.

We examined the profitability drivers for Islamic banks by testing the effect of independent variables on ROAA, ROAE, and NIM. The ROAA and ROAE models provided the same regression results with significant levels for all the selected independent variables, except for the ownership structure. The impact of ownership structure on Islamic banks ROAA showed negative 
coefficients for both privately and publicly owned banks. While we consider the previous results vague, the effect of ownership on ROAE and NIM models revealed more clear results. It showed that Islamic banks profitability increases when they are privately owned. This result is in line with the findings of Micco et al. (2007) who indicated that state-owned banks have lower profitability, which may be caused by high overhead costs. By testing whether having Islamic banks listed on the stock exchange had an effect on their performance, it was found that listed banks result in higher profitability levels. This shows that financial markets and the relevant stakeholders have a positive impact on Islamic banks performance. Listing Islamic banks on the stock exchanges not only enhances their performance, but also ensures Islamic banks compatibility and contribution to the relevant financial markets.

The equivalent bank age and liquidity risk reveal a positive effect on Islamic banks' profitability throughout the three models, which coincided with our expectations. Islamic banks with longer years of establishment incorporate higher profits. This shows that Islamic banks tend to benefit from the number of years of experience. Similar findings are revealed by Beck et al. (2013). Moreover, the resulting impact of liquidity risk on banks' profitability indicates that lower liquidity risk in banks implies higher liquid assets, which maintain bank stability on the expense of lower profits. Islamic banks face a liquidity management problem because of the lack of Shari'a compliant liquid assets that would enable banks to manage their liquidity efficiently (Salem, 2013). Hence, Islamic banks tend to maintain lower levels of liquidity risk as a safeguard for banking operations. Keeping low levels of liquidity risk have contributed to the stability and the resilience of the Islamic banking system since its inception and through the financial crisis of 2007.

Similarly, capitalization positively affects Islamic banks profitability. Previous empirical research, such as Hassan and Bashir (2003), revealed similar results for the effect of capital 
adequacy on Islamic banks performance. Even though Islamic banks lower their risk by maintaining relatively high capital levels, they manage to sustain high profits. This can either be explained that Islamic banks manage to lower their funding costs as a result of their increased credit worthiness, or are able to reduce the need for external funds. With regards to operating efficiency measured by the CIR, the results of our first two panels: ROAA and ROAE, concluded a negative impact of CIR on banks' profitability. This result adheres to our expectations and come out similar to Dietrich and Wanzenried (2014).

On the other hand, bank size, credit risk, and deposit growth rates have a negative and significant effect on profitability. The resulted impact of the bank size confirm with the findings of Stiroh and Rumble (2006). This may be referred to the bureaucracy of Islamic banks that disables the bank management to benefit from a larger bank size. Furthermore, an increase in credit risk has proven to cause a decline in profitability. Our conclusion adheres to Dietrich and Wanzenried (2014) and Tan (2016) who reported that higher credit risk negatively affects profitability. This implies that Islamic banks need to enhance credit quality and implement a qualified credit risk management system into their banking operations. Additionally, another variable that reveal a negative impact on the profitability of Islamic banks is deposit growth. Sufian (2011) reveals that deposit growth is an important determinant for banks' profitability as it facilitates lower cost of funds through attracting more deposits. However, our findings were contrary to our expectations and to the literature, revealing lower profitability levels accompanied with an increase of deposits. We explain this with the high cost of funds Islamic banks face in attracting deposits. It appears that Islamic banks are exposed to high operational expenditures without a reasonable return that covers such an exposure, which leads to lower profitability levels. Attracting deposits in Islamic banks could be more difficult because of their novelty, which could be a main contributor to this 
negative relationship. Another explanation could be that depositors' returns should be calculated based on the profit and loss sharing concept rather than mere calculation of interest rates that may result in relatively higher cost of funding.

On the macroeconomic level, real GDP growth rates and inflation provide a significant positive relationship on the first two panels of analysis. Macroeconomic indicators as measured in our models have a positive impact on profitability indicators measured by ROAA and ROAE while holding all other variables constant. Our results coincide with most of the empirical literature on the impact of GDP and inflation on banks

profitability (e.g. Molyneux and Thornton, 1992; Athanasoglou et al., 2008). Higher levels of profitability in this case is explained by the ability of banks to adjust to both GDP growth rates and interest rates. Banks are able to manage and adjust their operating expenses and revenues in a way that leads to higher profitability. On the contrary, both GDP growth rates and inflation resulted in a negative impact on profitability when measured by the NIM in the third panel. The latter concluded relationship does not match the other two panels and hence we leave our analysis at the positive impact concluded earlier based on the consensus of the results. 
Table 3: GMM Estimation results for:

Model 1 - ROA

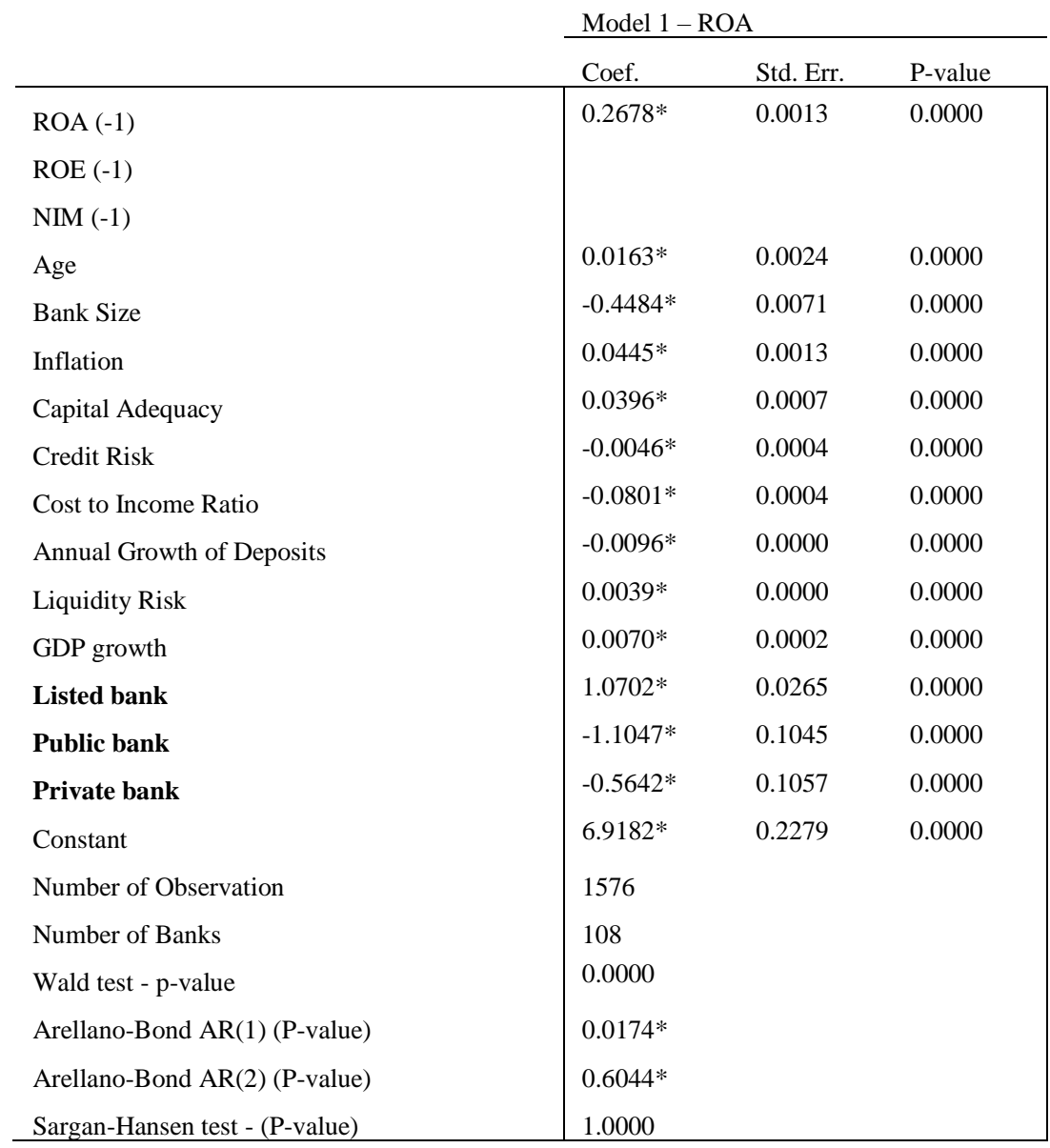

The tables show the output of GMM estimation of the three models.

$* \& * * \& * * *$ refer to $1 \%, 5 \%$ and $10 \%$ significance level respectively as the null hypotheses is the parameter is not significant $\left(\mathbf{H}_{0}: \boldsymbol{\beta}_{\mathrm{k}}=\mathbf{0}\right)$. 
Model 2 - ROE

\begin{tabular}{l|lll|} 
& \multicolumn{3}{l}{ Model 2 - ROE } \\
\cline { 2 - 4 } & Coef. & Coef. & Coef. \\
\hline ROA (-1) & & & \\
ROE (-1) & $0.2185^{*}$ & $0.2185^{*}$ & $0.2185^{*}$ \\
Age (-1) & & & \\
Bank Size & $0.1653^{*}$ & $0.1653^{*}$ & $0.1653^{*}$ \\
Inflation & $-1.4109^{*}$ & $-1.4109^{*}$ & $-1.4109^{*}$ \\
Capital Adequacy & $0.1431^{*}$ & $0.1431^{*}$ & $0.1431^{*}$ \\
Credit Risk & $0.2091^{*}$ & $0.2091^{*}$ & $0.2091^{*}$ \\
Cost to Income Ratio & $-0.0911^{*}$ & $-0.0911^{*}$ & $-0.0911^{*}$ \\
Annual Growth of Deposits & $-0.3777^{*}$ & $-0.3777^{*}$ & $-0.3777^{*}$ \\
Liquidity Risk & $-0.0841^{*}$ & $-0.0841^{*}$ & $-0.0841^{*}$ \\
GDP growth & $0.0089^{*}$ & $0.0089^{*}$ & $0.0089^{*}$ \\
Listed bank & $0.0237^{*}$ & $0.0237^{*}$ & $0.0237^{*}$ \\
Public bank & $5.6941^{*}$ & $5.6941^{*}$ & $5.6941^{*}$ \\
Private bank & $-1.3823^{* *}$ & $-1.3823^{* *}$ & $-1.3823^{* *}$ \\
Constant & $2.2855^{*}$ & $2.2855^{*}$ & $2.2855^{*}$ \\
Number of Observation & $23.7724^{*}$ & $23.7724^{*}$ & $23.7724^{*}$ \\
Number of Banks & 1576 & & \\
Wald test - p-value & 108 & & \\
Arellano-Bond AR(1) (P-value) & 0.0000 & & \\
Arellano-Bond AR(2) (P-value) & $0.0045^{*}$ & & \\
Sargan-Hansen test - (P-value) & $0.2806^{*}$ & & \\
\hline
\end{tabular}


Model 3 - NIM

\begin{tabular}{l|lll|} 
& \multicolumn{3}{l}{ Model 3 - NIM } \\
\cline { 2 - 4 } & Coef. & Coef. & Coef. \\
\hline ROA (-1) & & & \\
ROE (-1) & & & \\
NIM (-1) & $0.640)^{*}$ & $0.6409^{*}$ & $0.6409^{*}$ \\
Age & $0.1630^{*}$ & $0.1630^{*}$ & $0.1630^{*}$ \\
Bank Size & $-0.1091^{*}$ & $-0.1091^{*}$ & $-0.1091^{*}$ \\
Inflation & $-0.0163^{*}$ & $-0.0163^{*}$ & $-0.0163^{*}$ \\
Capital Adequacy & $0.1229^{*}$ & $0.1229^{*}$ & $0.1229^{*}$ \\
Credit Risk & $-0.0819^{*}$ & $-0.0819^{*}$ & $-0.0819^{*}$ \\
Cost to Income Ratio & $0.0017^{*}$ & $0.0017^{*}$ & $0.0017^{*}$ \\
Annual Growth of Deposits & $-0.0036^{*}$ & $-0.0036^{*}$ & $-0.0036^{*}$ \\
Liquidity Risk & $0.0410^{*}$ & $0.0410^{*}$ & $0.0410^{*}$ \\
GDP growth & $-1.2620^{*}$ & $-1.2620^{*}$ & $-1.2620^{*}$ \\
Listed bank & $3.6848^{*}$ & $3.6848^{*}$ & $3.6848^{*}$ \\
Public bank & $-0.7242^{*}$ & $-0.7242^{*}$ & $-0.7242^{*}$ \\
Private bank & $1.9044^{*}$ & $1.9044^{*}$ & $1.9044^{*}$ \\
Constant & $8.9738^{*}$ & $8.9738^{*}$ & $8.9738^{*}$ \\
Number of Observation & 1570 & & \\
Number of Banks & 108 & & \\
Wald test - p-value & 0.0000 & & \\
Arellano-Bond AR(1) (P-value) & $0.0617^{*}$ & & \\
Arellano-Bond AR(2) (P-value) & $0.2980^{*}$ & & \\
Sargan-Hansen test - (P-value) & 1.0000 & & \\
\hline & & & \\
\hline
\end{tabular}

Arellano-Bond $A R(1)$ \& Arellano-Bond AR(2) refers to Arellano-Bond test that detects if the average autocovariance of the residuals of order $1 \& 2$ are equal to zero or not ( $H_{0}$ : no autocorrelation). Sargan-Hansen test is for overidentifying restrictions in GMM estimation. 


\section{CONCLUSION}

This paper examined the main determinants of banks profitability on global panel data over the period $2005-2015$ by applying the GMM estimation model on panel data of 108 banks across 35 countries. We measured profitability using the ROAA, ROAE, and NIM. We categorized determinants that affect banks' performance into bank-specific and macroeconomic determinants. Our model showed a high degree of significance with highly similar results for the three models. We concluded that bank size, credit risk, CIR, and deposit growth rates have a negative relationship with profitability indicators with high significant levels. On the other hand, bank age, capital adequacy, liquidity risk, inflation, and GDP growth rates, positively impact banks profitability. Furthermore, it is concluded that listed banks are more profitable than unlisted banks, whereas the three models equally revealed that publically owned banks achieve lower profitability levels.

This research presented a critical analysis of the determinants of profitability for Islamic banks on the global level, while focusing on bank-specific and macroeconomic variables. Our findings provide a significant contribution to policy makers, bank management, regulators, and international bodies such as the AAOIFI. The findings can give better insights about the operation of Islamic banks in different countries and under various economic and regulatory environments. Adequate management of liquidity risk and credit risk should be addressed and its impact on profitability requires further investigation. Downsizing Islamic banks

should be considered as it seems that larger Islamic banks achieve lower profits, which means that those banks are beyond their 
efficient productive scale. Suggestions for future research would be further empirical investigation of our findings on different regions with in-depth study of the explanatory variables such as the deposit growth rate, to identify the reasons beyond the rendered relationships. In addition, further comparative investigation of the global panel of Islamic banks to study the determinants of profitability of Islamic banks across countries and include industry variables would also be of interest. Furthermore, including more risk measures and macroeconomic variables is recommended for future research. Finally, this study covered a rich research area that needs a considerable number of interesting investigations in different aspects.

\section{REFERENCES}

Abedifar, P., Ebrahim, M.S., Molyneux, P., Tarazi, A. (2015), "Islamic banking and finance: recent empirical literature and directions for future research", Journal of Economic Survey, Vol. 29, pp. 637-670.

Abedifar, P., Hasan, I., and Tarazi, A. (2016), "Finance-growth nexus and dual-banking systems: Relative importance of Islamic banks", Journal of Economic Behavior \& Organization, DOI: 15, March, 2016

Abedifar, P., Molyneux, P., and Tarazi, A. (2013), "Risk in Islamic Banking", Review of Finance, Vol. 17, pp. 2035-2096

Ahmed, A. M., and Khababa, N. (1999), "Performance of banking sector in Saudi Arabia", Journal of Financial Management and Analysis, Vol. 12, No. 2, pp. 30-36

Al-Tamimi, H. (2010), "Factors Influencing Performance of the UAE Islamic and Conventional National Banks", Global Journal of Business Research, Vol. 4, No. 2, pp. 1-11

Athanasoglou, P.P., Brissimis, S.N., and Delis, M. (2008), "Bank-specific, industry-specific and macroeconomic 
determinants of bank profitability", International Financial Markets, Institutions, \&Money, Vol. 18, pp. 121-136

Arellano, M., Bond, S. (1991), "Some tests of specification for panel data: Monte Carlo evidence and an application to employment equations", Review of Economic Studies, Vol. 58, No. 2, pp. 277-297.

Arellano, M., Bover, O. (1995), "Another look at the instrumental-variable estimation of error-components models", Journal of Econometrics, Vol. 68, No. 1, pp. 29-52.

Bader, M. K. I., Mohamad, S., Ariff, M., and Hassan, T. (2008), "Cost, revenue and profit efficiency of Islamic verses conventional banks: international evidence using data envelopment analysis", Islamic Economic Studies, Vol. 15, No. 2.

Baltagi, B.H. (2001). Econometric Analysis of Panel Data, 2nd ed. John Wiley \& Sons, Chichester.

Baltagi, B. H. (2005). Econometric analysis of panel data. England: John Wiley \& Sons Ltd, The Atrium, Southern Gate, Chichester, West Sussex PO19 8SQ.

Bashir, A. (1999), "Risk and profitability measures in Islamic banks: The case of two Sudanese banks", Islamic Economic Studies, Vol. 6, No. 2, pp. 1-24.

Beck, T., Demirguc-kun, A., Merrouche, O. (2013), "Islamic vs. conventional banking: business model, efficiency and stability", Journal of Banking and Finance, Vol. 37, pp. 443-447

Ben Khediri, K., Charfeddine, L., and Youssef, S. (2015), "Islamic versus conventional banks in the GCC countries: A comparative study using classification techniques", Research in International Business and Finance, Vol. 33, pp. 75-98 
Berger, A.N. (1995), "The relationship between capital and earnings in banking", Journal of Money Credit and Banking, Vol. 27, No. 2, pp. 432-456.

Berger, A.N., Bonime, S.D., Covitz, D.M., and Hancock, D. (2000), "Why are bank profits so persistent? The roles of product market competition, informational opacity, and regional/macroeconomic shocks", Journal of Banking and Finance, Vol. 24, pp. 1203-1235.

Demirguc-Kunt, A., Huizinga, H. (1999), "Determinants of commercial bank interest margins and profitability: some international evidence", World Bank Economic Review, Vol. 13, No. 2, pp. 379-408.

Dietrich, A., \& Wanzenried, G. (2011), "Determinants of bank profitability before and during the crisis: Evidence from Switzerland", Journal of International Financial Markets, Institutions and Money, Vol. 21, No. 3, pp. 307-327.

Dietrich, A., and Wanzenried, G. (2014), "The determinants of commercial banking profitability in low-middle-, and highincome countries", The Quarterly Review of Economics and Finance, Vol. 54, pp. 337-354

Daly, S., and Frikha, M. (2015). "Determinants of bank Performance: Comparative study between Conventional and Islamic banking in Bahrain", Journal of the Knowledge Economy, Vol. 6, pp. 1-18

El-Gamal, M.A. and Inanoglu, H. (2002). Efficiencies and unobserved heterogeneity in Turkish banking: 1990-2000, unpublished working paper, Rice University, Department of Economics.

Goddard, J., Molyneux, P., Wilson, J. (2004), "Dynamics of Growth and Profitability in Banking", Journal of Money, Credit and Banking, Vol. 36, No. 3, pp. 1069-1090 
Golin, J. (2001). The bank credit analysis handbook: A guide for analysts, bankers and investors. Asia: John Wiley \& Sons.

Grassa, R. (2012),"Islamic banks' income structure and risk: evidence from GCC countries", Accounting Research Journal, Vol. 25, No. 3, pp. 227 - 241

Gujarati, D. N. (2003). Basic econometric. Boston: McGraw Hill. Hassan, M.K., and Bashir, A. (2003), "Determinants of Islamic banking profitability", Paper presented at the ERF Tenth Annual Conference, Marakesh, Morocco, 16-18 December

IFSB (2010), Islamic Finance and Global Financial Stability: Islamic Financial Services Board (IFSB), Islamic Development Bank (IDB), and Islamic Research and Training Institute (IRTI). Iannotta, G., Nocera, G., \& Sironi, A. (2007), "Ownership structure, risk and performance in the European banking industry", Journal of Banking \& Finance, Vol. 31, No. 7, pp. 2127-2149.

Izhar, H. and Asutay, M. (2007), "Estimating the profitability of Islamic banking: evidence from bank Muamalat Indonesia", Review of Islamic Economics, Vol. 11, No. 2, pp. 17-29.

Javaid, S., Anwar, J., Zaman, K., \& Gafoor, A. (2011), "Determinants of bank profitability in Pakistan: Internal factor analysis:, Mediterranean Journal of Social Sciences, Vol. 2, No. 1, pp. 59-78.

Kosmidou, K. (2008), “The determinants of banks' profits in Greece during the period of EU financial integration", Managerial Finance, Vol. 34, No. 3, pp. 146-159

Majid, A.M., Nor, N.G., and Said, F.F. (2003), "Efficiency of Islamic banks in Malaysia", Paper presented to the Fifth International Conference on Islamic Economics and Banking, Bahrain, October, 7-9. 
Micco, A., Panizza, U., Yañez, M. (2007), "Bank ownership and performance. Does politics matter?" Journal of Banking and Finance, Vol. 31, pp. 219-241.

Mohamad, S., Hassan, T., and Bader, M.K.I. (2008), "Efficiency of conventional versus Islamic banks: International evidence using the stochastic frontier approach (SFA)", Journal of Islamic Economics, Banking and Finance, Vol. 4, No. 2, pp. 107-130.

Mokni, S.R, and Rachdi, H., (2014), "Assessing the bank profitability in the MENA region", International Journal of Islamic and Middle Eastern Finance and Management, Vol. 7, No. 3, pp. $305-332$

Molyneux, P., Thornton, J., (1992), "Determinants of European bank profitability: a note", Journal of Banking and Finance, Vol. 16, No. 6, pp. 1173-1178.

Olson, D., \& Zoubi, T. (2008), "Using accounting ratios to distinguish between Islamic and conventional banks in the GCC region", International Journal of Accounting, Vol. 43, pp. 45-65 Olson, D., \& Zoubi, T. (2011), "Efficiency and bank profitability in MENA countries", Emerging Markets Review, Vol. 12, pp. 94110.

Olson, D., \& Zoubi, T. (2016), "Convergence of bank performance for commercial and Islamic banks during and after the Global financial crisis", The Quarterly Review of Economics and Finance.

Pasiouras, F., \& Kosmidou, K. (2007), "Factors influencing the profitability of domestic and foreign commercial banks in the European Union", Research in International Business and Finance, Vol. 21, No. 2, pp. 222-237.

Perry, P. (1992), "Do banks gain or lose from inflation?", Journal of Retail Banking, Vol. 14, No. 2, pp. 25-30. 
Petria, N., Capraru, B., and Ihnatov, I. (2015), "Determinants of banks' profitability: evidence from EU 27 banking systems", Procedia Economics and Finance, Vol. 20, pp. 518-524

Ramadan, I. Z., Kilani, Q. A., \& Kaddumi, T. A. (2011), "Determinants of bank profitability: Evidence from Jordan", International Journal of Academic Research, Vol. 3, No. 4, pp. 180-191.

Ramlan, H., \& Adnan, M. S. (2016), "The Profitability of Islamic and Conventional Bank: Case Study in Malaysia", Procedia Economics and Finance, Vol. 35, pp. 359-367.

Rashwan, M. H. (2010). A comparison between Islamic and traditional banks: Pre and post the 2008 financial crisis, Available at SSRN: $\quad$ http://ssrn.com/abstract $=1724451 \quad$ or doi:10.2139/ssrn.1724451. (Last accessed May 8, 2015).

Revell, J., (1979). Inflation and Financial Institutions. Financial Times, London.

Rosly, S. A., and Abubakar, M. A. (2003), "Performance of Islamic and mainstream banks in Malaysia", International Journal of Social Economics, Vol. 30.

Rosman, R., Wahab, N. A., \& Zainol, Z. (2014), "Efficiency of Islamic banks during the financial crisis: An analysis of Middle Eastern and Asian countries", Pacific-Basin Finance Journal, Vol. 28, pp. 76-90.

Salem, R. A. (Eds.). (2013). Risk Management for Islamic Banks. Edinburgh: Edinburgh University Press.

Samad, A. (2004), "Performance of interest-free Islamic banks Vis-À-Vis interest-based conventional banks of Bahrain", IIUM Journal of Economics and Management, Vol. 12, No. 2.

Samad, A., and Hassan, M.K. (1999), "The performance of Malaysian Islamic bank during 1984-1997: an exploratory 
study", International Journal of Islamic Financial Services, Vol. 1, No. 3, pp. 1-14.

Staikouras, C., and Wood, G. (2004), "The determinants of European bank profitability", International Business and Economics Research Journal, Vol. 3, No. 6, pp. 57-68.

Stiroh, K., and Rumble, A. (2006), "The dark side of diversification: The case of US financial holding

companies", Journal of Banking and Finance, Vol. 30, No. 8, pp. 2131-2161.

Sufian, F. (2009), "Factors influencing bank profitability in a developing economy. Empirical evidence from Malaysia", Global Business Review, Vol. 10, No. 2, pp. 225-241.

Sufian, F. (2011), "Profitability of the Korean banking sector: panel evidence on bank-specific and macroeconomic determinants", Journal of. Economics and Management. Vol.7, No. 1, pp. 43-72.

Tan, Y. (2016), "The impacts of risk and competition on bank profitability in China", Journal of International Financial Markets, Institutions \& Money, Vol. 40, pp. 85-110.

Tan, Y., Floros, C. (2012), "Bank profitability and inflation: the case of China", Journal of Economic Studies, Vol. 39, No. 6, pp. 675-696.

Trad, N., Trabelsi, M. A., \& Goux, J. F. (2017), "Risk and profitability of Islamic and banks: A religious deception or an alternative solution?" European Research on Management and Business Economics, Vol. 23, No. 1, pp. 40-45.

Zarrouk, H., Ben Jedidia, K., and Moualhi, M. (2016), "Is Islamic bank profitability driven by same forces as conventional banks?", International Journal of Islamic and Middle Eastern Finance and Management, Vol. 9, No. 1, pp. 46-66 
